\title{
RESPON SISWA TERHADAP MODEL PEMBELAJARAN POE DALAM PEMBELAJARAN IPA DI SD
}

\author{
Budi1), Yogi Setya Novanto'), Rien Anitra') \\ 1)Departemen Pendidikan Guru Sekolah Dasar, STKIP Singkawang, Singkawang, Kalimantan Barat, Indonesia \\ Corresponding author : Yogi Setya Novanto \\ E-mail : yogisn2014@gmail.com
}

Diterima 30 Oktober 2021, Disetujui 05 November 2021

\begin{abstract}
ABSTRAK
Penelitian ini bertujuan untuk mendeskripsikan respon siswa terhadap penggunaan model pembelajaran POE (Predict, Observe, Explain) dalam pembelajaran IPA di SD. Penelitian ini dilaksanakan di MIS Ushuluddin Singkawang dan Subjek dalam penelitian ini adalah siswa kelas V sebanyak 28 siswa. Instrumen untuk pengumpulan data dalam penelitian ini adalah angket respon siswa. Teknik analisis data menggunakan metode deskriptif kuantitatif dengan persentase, untuk mengetahui respon positif siswa terhadap model pembelajaran POE dalam pembelajaran IPA. Hasil penelitian menunjukkan bahwa: Terdapat Respon siswa positif terhadap model pembelajaran POE diperoleh dari hasil persentase tiap indikator respon siswa, Untuk indikator relevansi terdapat persentase $81 \%$ dengan kriteria sangat baik, indikator perhatian terdapat $85 \%$ dengan kriteria sangat baik, indikator kepuasan terdapat persentase $87 \%$ dengan kriteria sangat baik, dan indikator percaya diri terdapat persentase $86 \%$ dengan kriteria sangat baik.
\end{abstract}

Kata kunci: Respon siswa; model pembelajaran Predict; Observe; Explain; pembelajaran IPA.

\begin{abstract}
This study aims to describe student responses to the use of the POE (Predict, Observe, Explain) learning model in science learning in elementary schools. This research was conducted at MIS Ushuluddin Singkawang and the subjects in this study were 28 students of class V. The instrument for collecting data in this study was a student response questionnaire. The data analysis technique used quantitative descriptive methods with percentages, to determine the positive response of students to the POE learning model in science learning. The results showed that: There was a positive student response to the POE learning model obtained from the results of the percentage of each student response indicator, for relevance indicators there was a percentage of $81 \%$ with very good criteria, $85 \%$ attention indicators with very good criteria, satisfaction indicators with a percentage of $87 \%$ with very good criteria, and the confidence indicator there is a percentage of $86 \%$ with very good criteria.
\end{abstract}

Keywords: Student responses; Predict; Observe; Explain learning models; science learning.

\section{PENDAHULUAN}

Karakteristik pembelajaran IImu Pengetahuan Alam (IPA) berkaitan dengan upaya memahami berbagai fenomena alam secara sistematis. Pembelajaran IPA sendiri mecakup sikap ilmiah IPA, proses ilmiah IPA dan aplikasi IPA. IImu Pengetahuan Alam dipahami sebagai ilmu yang lahir dan berkembang lewat langkah-langkah observasi, perumusan masalah, penyusunan hipotesis, pengajuan hipotesis melalui eksperimen, penarikan kesimpulan serta penemuan teori dan konsep. Menurut (Susanto, 2016) IPA adalah usaha manusia dalam memahami alam semesta melalui pengamatan yang tepat pada sasaran, serta menggunakan prosedur, dan dijelaskan dengan penalaran sehingga mendapatkan suatu kesimpulan. Melalui pembelajaran IPA siswa dapat memperoleh pengalaman langsung dalam mempelajari gejala alam semesta melalui pengamatan dan hasilnya dapat disimpulkan dengan penalaran manusia.

Pentingnya pelajaran IPA di SD menjadikan siswa untuk berpikir secara positif yang memberikan dampak baik sehingga siswa menjadi tahu tentang teknologi dan ramah lingkungan sebagai elaborasi dari membaca IPA (Mariana \& Praginda, 2009). Pembelajaran IPA pada anak SD juga mengajarkan cara memecahkan masalah, melatih kemampuan pemahaman, mengambil kesimpulan, melatih bersikap objektif, bekerja sama dan menghargai pendapat orang lain. Kenyataannya, pembelajaran IPA siswa masih tergolong rendah. Hal ini dibuktikan dengan 
hasil penelitian dari Trend in Internasional Mathematic and Science Study 2015 dalam (Hadi \& Novaliyosi, 2019) bidang sains, Indonesia menduduki peringkat 44 dari 49 ratarata skor Indonesia 397 dan jauh di bawah ratarata internasional yaitu 500. Hasil penelitian (Widiawati et al., 2015) berjudul Analisis Pemahaman Konsep dalam Pelajaran IPA pada siswa kelas IV SD di Gugus II Kecamatan Banjar juga menunjukkan bahwa kemampuan pemahaman konsep IPA siswa di Sekolah Dasar tempat penelitiannya masih rendah, bahwa $10,81 \%$ peserta didik memperoleh nilai rata-rata dari tes pemahaman konsep IPA, sebanyak $45,95 \%$ peserta didik memperoleh nilai dibawah rata-rata dan sebanyak $43,24 \%$ peserta didik memperoleh nilai diatas rata-rata, sehingga perlu ditingkatkan.

Rendahnya pembelajaran IPA siswa juga terjadi di MIS Ushuluddin Singkawang. Dari hasil observasi yang dilakukan pada bulan februari 2020, diperoleh pembelajaran IPA siswa rendah, dimana hasil uji coba tes soal yang diberikan kepada siswa rata-rata nilai yang didapat sebesar 55 . Hal seperti ini dapat berdampak buruk bagi peserta didik yang tidak paham konsep sehingga ada masalah pada pemahaman konsep peserta didik. Saat melakukan wawancara dengan guru kelas $\mathrm{V}$, guru menyatakan bahwa siswa masih banyak yang belum paham tentang pelajaran IPA terutama jika membahas tentang sebuah konsep pada materi panas dan perpindahannya. Adapun menurut peserta didik yang diwawancarai oleh peneliti, dalam proses pembelajaran guru hanya menggunakan model pembelajaran langsung, guru juga tidak mengajak peserta didik untuk melakukan praktikum.

Hal tersebut diduga terjadi karena proses pembelajaran IPA yang berlangsung masih berpusat pada guru. Peserta didik kurang terlibat dalam kegiatan pembelajaran IPA, ketika guru menjelaskan, guru tidak memberikan kesempatan kepada siswa untuk bertanya sehingga berdampak pada pemahaman siswa akan infomasi yang diterimanya rendah. Kondisi seperti ini dapat diatasi dengan menerapkan model pembelajaran yang tepat untuk pembelajaran IPA. Pada pembelajaran IPA banyak modelmodel pembelajaran yang bisa digunakan pada proses pembelajarannya. Salah satunya yang dapat diterapkan adalah model pembelajaran Predict-Observe-Explain (POE).

Menurut (Juniari et al., 2014), POE merupakan salah satu model yang dapat membantu mengaktifkan siswa dalam proses pembelajaran karena pada model ini peserta didik tidak hanya mendengarkan tetapi juga mengamati peristiwa yang terjadi. POE merupakan model pembelajaran yang memiliki tugas utama yang harus dijalankan siswa yaitu, memprediksi, mengamati, menjelaskan. Dari langkah-langkah tersebut dapat dijelaskan bahwa (1) prediksi (predict), misalnya siswa mengamati demonstrasi perpindahan panas secara konduksi guru memegang batang besi yang dibakar dengan korek api dan siswa langsung memprediksi apa yang terjadi dengan batang besi tersebut dan tangan guru. (2) pengamatan (observe), misalnya siswa mencatat dan mempraktikannya dengan memegang besi yang dibakar korek api untuk membuktikan apakah prediksinya benar. (3) penjelasan (explain), misalnya siswa mengajukan prediksi mengenai pengamatan, misalnya prediksinya besi tersebut panas dan membuat tangan menjadi panas, jika prediksi dan praktiknya benar siswa merangkum dan menjelaskannya lebih lengkap, jika prediksi dan praktiknya berbeda siswa dapat menjelaskan perbedaan antara prediksi yang dibuat siswa dan hasil praktiknya.

Hubungan model pembelajaran POE dengan pelajaran IPA adalah guru menjelaskan materi menggunakan model pembelajaran $\mathrm{POE}$ sesuai indikator kemampuan pemahaman konsep IPA mulai dari menjelaskan, mencontohkan, membandingkan, mengklasifikasikan, menyimpulkan begitu juga siswa dalam pembelajaran siswa menjelaskan prediksinya, mencontohkan demonstrasi dengan contoh yang lain, membandingkan prediksinya dengan pengamatannya, mengklasifikasikan prediksi dengan demonstrasi, dan menyimpulkan hasil prediksi dan hasil pengamatan yang benar. Adapun penelitian yang menyatakan model pembelajaran POE dapat meningkatkan kemampuan pemahaman konsep IPA siswa di SD. Hasil penelitian (Nugraha et al., 2019) menunjukan bahwa model pembelajaran POE dapat meningkatkan pemahaman konsep IPA siswa. Selain itu, hasil penelitian (Andriani et al., 2019) juga menunjukan bahwa penerapan model pembelajaran POE yang berorientasi Chemoentrepreneurship berpengaruh terhadap pemahaman konsep IPA siswa. Respon siswa akan rendah jika siswa kurang tertarik. Untuk mengetahui respon siswa, dapat menggunakan angket respon siswa.

Angket menurut Riduwan (2007) adalah daftar pertanyaan yang diberikan kepada subjek penelitian. Informasi yang diperoleh melalui angket dapat memberikan gambaran (deskripsi) tentang karakteristik dari individu atau sekelompok responden. Angket terdiri atas dua aspek, yaitu tanggapan dan reaksi. Pada aspek tanggapan terdiri atas dua 
indikator, yaitu format dan relevansi. Sementara aspek reaksi terdiri atas tiga indikator, yaitu keterkaitan, kepuasan dan percaya diri. Respon siswa adalah tingkah laku atau reaksi siswa selama mengikuti kegiatan pembelajaran, suatu respon bisa muncul apabila melibatkan panca indra dalam mengamati dan memperhatikan suatu obyek pengamatan. Terdapat beberapa faktor yang mempengaruhi adanya suatu respon, proses belajar, dan nilai kepribadian (Arini \& Lovisia, 2019). Sejalan dengan pernyataan di atas menunjukkan bahwa respon dapat berupa persyaratan dalam bentuk pendapat yang dianggap baik memenuhi syarat secara rasional dapat dikemukakan sehingga dapat disimpulkan bahwa respon adalah kesan atau reaksi setelah kita mengamati aktifitas mengindra, menilai, objek terbentuknya sikap terhadap objek tersebut dapat berupa sikap negatif dan positif (Hidayati \& Muhammad, 2013).

\section{METODE PENELITIAN}

Metode penelitian menurut Sugiyono (2015) pada dasarnya merupakan cara ilmiah untuk mendapatkan data dengan tujuan dan kegunaan tertentu. Adapun metode yang digunakan dalam penelitian ini adalah metode penelitian deskriptif. (Effendi \& Tukiran, 2012) mengemukakan bahwa penelitian deskriptif dimaksudkan untuk mengukur dengan cermat fenomena sosial tertentu, peneliti mengembangkan konsep dan menghimpun fakta, tetapi tidak melakukan pengujian hipotesis.

Penelitian ini dilaksanakan di MIS Ushuluddin Singkawang. Waktu penelitian dilaksanakan pada semester genap tahun ajaran 2020/2021. Subjek dalam penelitian ini adalah siswa kelas VB berjumlah 28 siswa. Adapun objek dalam penelitian ini adalah respon siswa terhadap model pembelajaran POE dalam pembelajaran IPA. Teknik pengumpulan data adalah cara-cara yang dapat digunakan oleh peneliti untuk mengumpulkan data (Riduwan, 2009). Adapun Teknik pengumpulan data yang digunakan pada penelitian ini adalah teknik tes. Tes yang digunakan adalah berupa lembar respon siswa yang dilaksanakan sesudah model pembelajaran POE dilaksanakan. Lembar respon siswa terdiri dari 16 butir pernyataan yang terdiri dari indikator relevansi, perhatian, kepuasan, dan percaya diri. Analisis data angket respon siswa terhadap model pembelajaran POE menggunakan cara skala guttman (Sugiyono, 2015). Setelah peneliti mengumpulkan data melalui angket langkah selanjutnya adalah menganalisis data. Teknik analisis data yang digunakan dalam penelitian ini adalah teknik analisis deskpritif kuantitatif dengan presentase, dengan tujuan untuk mengetahui respon siswa terhadap model pembelajaran POE dalam pembelajaran IPA.

\section{HASIL DAN PEMBAHASAN \\ Angket respon siswa}

Respon siswa terhadap model pembelajaran POE pada materi panas dan perpindahannya diperoleh melalui lembar angket respon siswa yang disebarkan kepada seluruh siswa kelas eksperimen yang berjumlah 28 siswa. Data yang disajikan berupa tanggapan terhadap pernyataan-pernyataan yang terdapat pada angket respon siswa. Berdasarkan hasil analisis respon siswa, maka kriteria angket respon siswa sebagai berikut:

Tabel 1. Kriteria Angket Respon Siswa.

\begin{tabular}{ll}
\hline Persentase (\%) & Kriteria \\
\hline $0 \%<\mathrm{P}<25 \%$ & Jelek \\
\hline $25 \% \leq \mathrm{P}<50 \%$ & Cukup \\
\hline $50 \% \leq \mathrm{P}<75 \%$ & Baik \\
\hline $75 \% \leq \mathrm{P} \leq 100 \%$ & Sangat Baik \\
\hline & (Arini \& Lovisia, 2019)
\end{tabular}

Adapun hasil persentase angket respon siswa disajikan dalam bentuk diagram batang sebagai berikut:

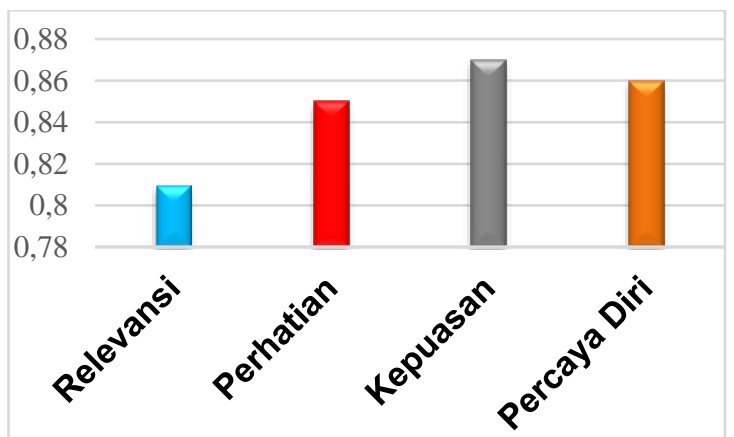

Gambar 1. Diagram Batang Respon Siswa Tiap Indikator

Berdasarkan gambar 1, diketahui persentase respon siswa pada indikator relevansi terhadap model pembelajaran POE mencapai $81 \%$, untuk persentase respon siswa pada indikator perhatian menggunakan model pembelajaran POE mencapai $85 \%$, persentase respon siswa pada indikator kepuasan mencapai $87 \%$, sedangkan persentase respon siswa pada indikator percaya diri $86 \%$. Dengan demikian, dapat dikatakan bahwa seluruh indikator respon siswa masuk kriteria sangat baik sehingga, respon siswa positif terhadap pembelajaran IPA dengan menggunakan model pembelajaran POE pada materi panas dan perpindahannya. 


\section{Pembahasan}

\section{Hasil analisis respon siswa}

Respon siswa terhadap pembelajaran IPA dengan menggunakan model pembelajaran POE menunjukkan tanggapan yang positif. Hal ini di tunjukkan dengan perolehan persentase hasil angket respon siswa pada tiap indikatornya, untuk indikator respon siswa relevansi terhadap pembelajaran IPA menggunakan model pembelajaran $\mathrm{POE}$ dengan persentase $81 \%$ dengan kriteria sangat baik, untuk indikator perhatian terhadap pembelajaran IPA menggunakan model pembelajaran POE dengan persentase $85 \%$ dengan kriteria sangat baik, pada indikator kepuasan terhadap pembelajaran IPA menggunakan model pembelajaran $\mathrm{POE}$ dengan persentase $87 \%$ dengan kriteria sangat baik, sedangkan indikator percaya diri terhadap pembelajaran IPA menggunakan model pembelajaran POE dengan persentase 86\% dengan kriteria sangat baik. Pernyataan tersebut sejalan dengan hasil penelitian dari (Andriani et al., 2019) penggunaan model pembelajaran POE berpengaruh positif terhadap pemahaman konsep siswa.

Dari uraian diatas, dapat disimpulkan bahwa pembelajaran menggunakan model pembelajaran POE pada matari panas dan perpindahannya berpengaruh pada kemampuan pemahaman konsep IPA siswa, sehingga siswa merespon dengan baik kegiatan pembelajaran. Pernyaataan ini sesuai dengan hasil penelitian (Murdani et al., 2017) yang menyatakan model pembelajaran $\mathrm{POE}$ dapat meningkatkan pemahaman konsep siswa yang berujung pada respon positif terhadap penggunaan model tersebut. Adapun Hasil penelitian yang mendukung hal tersebut (Muliyani, 2015) yang menjelaskan penggunaan model pembelajaran POE dapat meningkatkan kemampuan pemahaman konsep sehingga tujuan dan proses pembelajaran akan tercapai lalu respon siswa saat belajar menggunakan model pembelajaran POE sangat positif.

\section{SIMPULAN DAN SARAN SIMPULAN}

Berdasarkan hasil perhitungan data penelitian dan pembahasan secara umum dapat disimpulkan bahwa, Terdapat respon positif siswa terhadap model pembelajaran POE pada pelajaran IPA kelas $V$ di MIS Ushuluddin Singkawang diperoleh dari hasil persentase tiap indikator respon siswa dengan kriteria sangat baik.

\section{Saran}

Berdasarkan hasil penelitian terdapat saran yaitu, bagi Kepala Sekolah, guru dan seluruh yang terlibat dalam pendidikan untuk selalu berinovasi dan berkreasi dalam menentukan model pembelajaran supaya dalam pembelajaran tidak menoton dan pembelajaran lebih menyenangkan serta siswa menjadi mudah memahami pembelajaran.

\section{UCAPAN TERIMAKASIH}

Ucapan terimakasih disampaikan kepada Kepala Madrasah, guru, dan siswa kelas V di MIS Ushuluddin Singkawang sehingga penelitian ini dapat dilakukan dengan baik. Kemudian ucapan terimakasih juga disampaikan kepada STKIP Singkawang yang telah memfasilitasi peneliti dalam menyelesaikan artikel ini.

\section{DAFTAR RUJUKAN}

Andriani, R., Muhali, M., \& Dewi, C. A. (2019). Pengaruh Model Pembelajaran POE (Predict-Observe-Explain) Berorientasi Chemoentrepreneurship Terhadap Pemahaman Konsep Siswa Pada Materi Larutan Penyangga. Hydrogen: Jurnal Kependidikan Kimia, 5(2), 94. https://doi.org/10.33394/hjkk.v5i2.1649

Arini, W., \& Lovisia, E. (2019). Respon Siswa Terhadap Media Pembelajaran Alat Pirolisis Sampah Plastik Berbasis Lingkungan Di Smp Kabupaten Musi Rawas. Thabiea: Journal of Natural Science Teaching, 2(2), 95-104. https://doi.org/10.21043/thabiea.v2i2.595 0

Effendi \&, \& Tukiran. (2012). Metode Penelitian Survei. LP3ES.

Hadi, S., \& Novaliyosi. (2019). TIMSS Indonesia (Trends in International Mathematics and Science Study). Prosiding Seminar Nasional \& Call For Papers Program Studi Magister Pendidikan Matematika Universitas Siliwangi, 562-569.

Hidayati \& Muhammad. (2013). Respon Guru dan Siswa terhadap Pembelajaran Permainan Bolavoli yang dilakukan dengan Pendekatan Modifikasi (Pada Siswa Kelas V SDN Wateswinagun I Lamongan). Jurnal Pendidikan Olahraga Dan Kesehatan, 1 (1).

Juniari, N. K., Kusmariyatni, N. N., \& Margunayasa, I. G. (2014). Pengaruh Model Pembelajaran Poe Dan Motivasi Belajar Terhadap Hasil Belajar Ipa Siswa Kelas V Sd. Jurnal Mimbar PGSD Universitas Pendidikan Ghanesha, 9(5), $1-12$.

Mariana, I. M. A., \& Praginda, W. (2009). Hakikat IPA dan Pendidikan IPA. Pusat Pengembangan dan Pemberdayaan 
Pendidik dan Tenaga Kependidikan IImu Pengetahuan Alam (PPPPTK IPA).

Muliyani, R. (2015). PENGARUH PENERAPAN MODEL PEMBELAJARAN

PREDICT_OBSERVE-EXPLAIN (POE) BERBANTUUN REFUTATION TEXT TERHADAP PEMAHAMAN PENINGKATAN

KONSEP MISKONSEPSI SISWA SMP PADA MATERI FLUIDA STATIS.

Nugraha, D. A., Dimas, A., Cari, C., Suparmi, A., \& Sunarno, W. (2019). Meta Analisis Pengaruh Model Pembelajaran POE Terhadap Pemahaman Konsep. Prosiding SNFA (Seminar Nasional Fisika Dan Aplikasinya), 4, 174. https://doi.org/10.20961/prosidingsnfa.v4i 0.37768

Riduwan. (2007). Skala Pengukuran VariabelVariabel Penelitian. Alfabeta.

Riduwan. (2009). Dasar-Dasar Statistika. Alfabeta.

Siswa, K., Materi, P., \& Newton, H. (2017). IMPLEMENTASI MODEL

PEMBELAJARAN POE （ PREDICT OBSERVE EXPLAIN ) UNTUK MENINGKATKAN PEMAHAMAN KONSEP SISWA PADA MATERI HUKUM NEWTON Haris Rosdianto , Eka Murdani, Hendra Sekolah Tinggi Keguruan dan IImu Pendidikan email: hendraeend641@gmail.com THE IMPLE. $6(1), 55-58$.

Sugiyono. (2015a). Metode Penelitian Pendidikan Pendekatan Kuantitatif, Kualitatif, dan R\&D. Alfabeta.

Sugiyono. (2015b). Metode Penelitian Pendidikan Pendekatan Kuantitatif, Kualitatif, dan R\&D. Alfabeta.

Susanto. (2016). Teori Belajar dan Pembelajaran di Sekolah Dasar. Kencana.

Widiawati, N. P., Pudjawan, K., \& Margunayasa, I. G. (2015). Analisis pemahaman konsep dalam pembelajaran IPA pada siswa kelas IV SD di gugus II kecamatan banjar. EJournal PGSD Universitas Pendidikan Ganesha, 3(1), 12-14. https://ejournal.undiksha.ac.id/index.php/ JJPGSD/article/view/5847 